\section{Year-round Production of Flowering Calathea crocata: Influence of Light and Carbon Dioxide}

\author{
Johan M. Van Huylenbroeck ${ }^{1}$ and Pierre C. Debergh \\ Faculty of Agricultural and Applied Biological Sciences, Department of Plant \\ Production, Laboratory of Horticulture, University of Gent, Coupure links \\ 653, B-9000 Gent, Belgium
}

Additional index words. multilayer growing room, photoperiod

\begin{abstract}
Programmed flower induction of Calathea crocata Morr. et Joris is possible under the controlled environmental conditions of a multilayer growing room. A photoperiod of 10 hours for 9 weeks, growth at $18 \mathrm{C}$, and a photosynthetic photon flux density (PPFD) of $71 \mu \mathrm{mol} \cdot \mathrm{s}^{-1} \cdot \mathrm{m}^{-2}$ induced flowering in more than $95 \%$ of the plants and in $\mathbf{5 0 \%}$ to $80 \%$ of the shoots. In the meantime, none of the plants under natural conditions was induced. Significantly more flowers were induced when PPFD during the short-day treatment was 71 rather than $56 \mu \mathrm{mol} \cdot \mathrm{s}^{-1} \cdot \mathrm{m}^{-2}$. Flowers became visible 14 to 16 weeks after the start of the inductive treatment. Moreover, raising the $\mathrm{CO}_{2}$ concentration to $900 \mathrm{ppm}$ for 5 months increased the leaf area and dry weight by $40 \%$, and resulted in darker leaf color, longer flower stalks, and significantly accelerated flowering (10 days).
\end{abstract}

Many Marantaceae, mainly those belonging to the genera Calathea and Maranta, are common houseplants, valued for their variegated leaf color. Only Calathea crocata is cultivated commercially as a flowering potted plant. Leaf blades are 10 to $15 \mathrm{~cm}$ long, ovatelanceolate, and somewhat undulate. Leaves are dark green adaxially and rose-purple abaxially. The capitate inflorescence is a short spike with bright saffron-yellow bracts (Bailey, 1950; Kennedy, 1977; Schumann, 1902).

Under northern European conditions, $C$. crocata flowers during winter; therefore, the sales period is limited from December until March. Flowering depends on daylength and temperature. Flower induction requires a photoperiod of $\approx 8$ to $11 \mathrm{~h} \cdot$ day $^{-1}$ and temperatures between 18 and 21C. Maximum daylength decreases as temperature increases $(15 \mathrm{~h}$ at $18 \mathrm{C}$ and $14 \mathrm{~h}$ at 21C) (Vonk-Noordegraaf, 1980; Zimmer, 1976). Consequently, excellent control of environmental conditions would be required for commercial year-round production of $C$. crocata. Such control is difficult to realize in a greenhouse during spring and summer. Therefore, the use of a multilayer growing room (MGR), as used by Pieters et al. (1989), where optimal environmental control was combined with optimal use of the available space, was evaluated for summer production. In preliminary work, Pieters et al. (1989) demonstrated that an MGR could be used for

Received for publication 28 Dec. 1992. Accepted for publication 22 Apr. 1993. The research was financially supported by Het instituut tot Aanmoediging van het Wetenschappelijk Onderzoek in Nijverheid en Landbouw (IWONL), grant no. 5411A. The cost of publishing this paper was defrayed in part by the payment of page charges. Under postal regulations, this paper therefore must be hereby marked advertisement solely to indicate this fact.

'To whom reprint requests should be addressed. 0.81 -liter $(13-\mathrm{cm})$ pots for $\mathrm{G}$ types and in 0.38 once by vegetative division and planted in liter $(10-\mathrm{cm})$ pots for $S$ types. At the start of the

YIndicates SE. experiments, plants were 10 (S clone) or 14 (G clone) months old. Potting medium was coarse ST 400-Finnpeat (DEGA potgrond, Delft, Netherlands; electrical conductivity $=1.0$ $\mathrm{dS} \cdot \mathrm{m}^{-1}$ and $\left.\mathrm{pH}=5.5\right)$. Flowering during Winter 1988 and 1989 was prevented by extending the natural photoperiod to $16 \mathrm{~h} \cdot \mathrm{day}^{-1}$ with high-pressure mercury-iodide lamps [Philips HPI-T400W; photosynthetic photon flux density $(\mathrm{PPFD})=50 \mu \mathrm{mol} \cdot \mathrm{s}^{-1} \cdot \mathrm{m}^{-2}$ at plant level $]$. Plants were fertilized regularly with Flory 3 (Planta, Regenstauf, Germany) at $1 \mathrm{~g} \cdot$ liter $^{-1}$ $(15 \mathrm{~N}-11 \mathrm{P}-15 \mathrm{~K}+1)$ and treated for red spider mite control.

Flower induction took place in four MGR ( $2.90 \times 5.60 \times 2.90 \mathrm{~m}$ high). Each room had four levels $(4.07 \times 1.37 \mathrm{~m})$, and the distance between the levels was $67.5 \mathrm{~cm}$. Light in the MGR was provided by fluorescent lamps (Philips TL'D 83) in combination with incandescent lamps (Osram $60 \mathrm{~W})$. The SDT, based on experiments by Pieters et al. (1989), lasted 9 weeks. Photoperiod was 10 h, relative humidity fluctuated between $65 \%$ and $80 \%$, and the day/night cycle was $18 / 17 \pm 1 \mathrm{C}$. Before and after induction, plants were placed in a standard greenhouse at $21 \mathrm{C}$.

Type $\mathrm{G}$ plants were used in Expt. 1. The SDT was given from 8 Aug. to 11 Oct. 1989. We investigated the influence of PPFD (56 or $\left.71 \mu \mathrm{mol} \cdot \mathrm{s}^{-1} \cdot \mathrm{m}^{-2}\right)$ and $\mathrm{CO}_{2}$ concentration $(400$ or $800 \mathrm{ppm}$ ) during the SDT. Before and after the SDT, the plants were placed in a greenhouse at a normal $\mathrm{CO}_{2}$ concentration, and the photoperiod was extended to $16 \mathrm{~h} \cdot \mathrm{day}^{-1}$ with high-pressure mercury-iodide lamps (PPFD = $50 \mu \mathrm{mol} \cdot \mathrm{s}^{-1} \cdot \mathrm{m}^{-2}$ at plant level).

Type $\mathrm{G}$ and $\mathrm{S}$ plants were used in Expt. 2. The SDT was given from 10 July to 11 Sept. 1990. During the SDT, PPFD was $71 \mu \mathrm{mol} \cdot \mathrm{s}^{-1} \cdot \mathrm{m}^{-2}$. We examined the influence of increased $\mathrm{CO}_{2}$ concentration (400 or $900 \mathrm{ppm}$, starting 10 June) on growth and flowering, and the effect of additional light after the SDT. Additional light was provided by high-pressure mercury-iodide lamps (PPFD $50 \mu \mathrm{mol} \cdot \mathrm{s}^{-1} \cdot \mathrm{m}^{-2}$ at plant level) from 0300 to 0900 HR and from 1700 to 2130 HR during Sept. and Oct. 1990. The daily light sum for plants grown under additional light was $\approx 30 \%$ higher than for those grown under natural conditions. Before the SDT, the experimental plants were maintained under a $16-\mathrm{h}$ photoperiod for all treatments.

Table 1. Effects of photosynthetic photon flux density (PPFD) and $\mathrm{CO}_{2}$ concentration during short-day treatment (SDT) on flowering of Calathea crocata clone G (Expt. 1).

\begin{tabular}{lccccc}
\hline $\begin{array}{l}\text { PPFD } \\
\text { during SDT } \\
\left(\mu \mathrm{mol} \cdot \mathrm{s}^{-1} \cdot \mathrm{m}^{-2}\right)\end{array}$ & $\begin{array}{c}\mathrm{CO}_{2} \text { level } \\
\text { during SDT } \\
(\mathrm{ppm})\end{array}$ & $\begin{array}{c}\text { Inflores- } \\
\text { cences/ } \\
\text { plant }(\mathrm{no} .)\end{array}$ & $\begin{array}{c}\text { Flowering } \\
\text { plants } \\
(\%)\end{array}$ & $\begin{array}{c}\text { Flowering } \\
\text { shoots } \\
(\%)\end{array}$ & $\begin{array}{c}\text { Flowering } \\
\text { date }^{2}\end{array}$ \\
\hline 56 & 400 & $3.0 \pm 0.2^{y}$ & $94 \pm 3$ & $56 \pm 4$ & $104 \pm 1$ \\
& 900 & $3.5 \pm 0.2$ & $97 \pm 3$ & $71 \pm 4$ & $96 \pm 1$ \\
71 & 400 & $3.7 \pm 0.4$ & $98 \pm 1$ & $69 \pm 7$ & $98 \pm 1$ \\
& 900 & $4.2 \pm 0.1$ & $100 \pm 0$ & $74 \pm 1$ & $93 \pm 1$ \\
Significance & & $*$ & & & $*$ \\
$\quad$ Light & & NS & NS & NS & $*$ \\
$\mathrm{CO}_{2}$ & & NS & NS & NS & NS \\
$\quad$ Light $\times \mathrm{CO}_{2}$ & & & & & NS \\
\hline
\end{tabular}

${ }^{2}$ Days to flowering from start of SDT (8 Aug. 1989) for all treatments.

ws,", "Nonsignificant or significant at $P=0.05$ or 0.01 , respectively, using analysis of variance. 
Table 2. Effects of $\mathrm{CO}_{2}$ concentration during culture [starting 1 month before short-day treatment (SDT)] and additional light after SDT on flowering of Calathea crocata clones G and S (Expt. 2).

\begin{tabular}{|c|c|c|c|c|c|c|}
\hline $\begin{array}{l}\mathrm{CO}_{2} \text { level } \\
(\mathrm{ppm})\end{array}$ & $\begin{array}{c}\text { Additional } \\
\text { light }^{z}\end{array}$ & $\begin{array}{l}\text { Inflores- } \\
\text { cences/ } \\
\text { plant (no.) }\end{array}$ & $\begin{array}{c}\text { Flowering } \\
\text { plants } \\
(\%)\end{array}$ & $\begin{array}{c}\begin{array}{c}\text { Flowering } \\
\text { shoots } \\
(\%)\end{array} \\
\end{array}$ & $\begin{array}{c}\text { Flowering } \\
\text { date }^{y}\end{array}$ & $\begin{array}{c}\text { Peduncle } \\
\text { length }(\mathrm{cm})\end{array}$ \\
\hline & & & Clone $G^{-}$ & & & \\
\hline \multirow[t]{2}{*}{400} & None & $3.6 \pm 0.4^{x}$ & $94 \pm 6$ & $69 \pm 4$ & $113 \pm 1$ & $26.3 \pm 1.2$ \\
\hline & Yes & $3.2 \pm 0.3$ & $94 \pm 6$ & $79 \pm 12$ & $106 \pm 1$ & $31.1 \pm 0.7$ \\
\hline \multirow[t]{2}{*}{900} & None & $3.7 \pm 0.6$ & $100 \pm 0$ & $78 \pm 13$ & $100 \pm 1$ & $32.2 \pm 0.8$ \\
\hline & Yes & $4.7 \pm 0.7$ & $94 \pm 6$ & $91 \pm 5$ & $99 \pm 2$ & $29.5 \pm 1.1$ \\
\hline \multicolumn{7}{|l|}{ Significance } \\
\hline $\mathrm{CO}_{2}$ & & NS & NS & NS & $* *$ & $* *$ \\
\hline Light & & NS & NS & NS & $*$ & NS \\
\hline \multirow[t]{2}{*}{$\mathrm{CO}_{2} \times$ light } & & NS & NS & NS & $* *$ & $*$ \\
\hline & & & Clone S & & & \\
\hline \multirow[t]{2}{*}{400} & None & $0.8 \pm 0.3$ & $62 \pm 12$ & $15 \pm 5$ & $109 \pm 5$ & $22.6 \pm 1.4$ \\
\hline & Yes & $2.1 \pm 0.5$ & $88 \pm 6$ & $40 \pm 10$ & $117 \pm 6$ & $22.4 \pm 1.0$ \\
\hline \multirow[t]{2}{*}{900} & None & $2.6 \pm 0.4$ & $94 \pm 6$ & $51 \pm 7$ & $100 \pm 3$ & $24.9 \pm 1.5$ \\
\hline & Yes & $2.5 \pm 0.5$ & $94 \pm 6$ & $51 \pm 9$ & $97 \pm 1$ & $26.3 \pm 1.4$ \\
\hline \multicolumn{7}{|l|}{ Significance } \\
\hline $\mathrm{CO}_{2}$ & & * & * & * & ** & ** \\
\hline Light & & NS & NS & NS & NS & NS \\
\hline $\mathrm{CO}_{2} \times$ light & & NS & NS & NS & NS & NS \\
\hline
\end{tabular}

${ }^{z}$ Additional light from high-pressure mercury-iodide lamps (photosynthetic photon flux density $=50$ $\mu \mathrm{mol} \cdot \mathrm{s}^{-1} \cdot \mathrm{m}^{-2}$ at plant level) from 0300 to $0900 \mathrm{HR}$ and from 1700 to $2130 \mathrm{HR}$.

${ }^{y}$ Days to flowering from start of SDT (10 July 1990) for all treatments.

${ }^{x}$ Indicates SE.

ss,****Nonsignificant or significant at $P=0.05$ or 0.01 , respectively, using analysis of variance

The following characteristics were scored: number of shoots, presence of visible flower buds, number of flowering plants, total number of flowers, and peduncle length. Additionally, in Expt. 2, the leaf areas and dry weights of type $\mathrm{S}$ plants were measured at the beginning (10 June 1990) and at the end (15 Nov. 1990) of the experiment. These latter data were obtained nondestructively, using image analysis (Sky Instruments, Powys, Wales; SI 700/705/710). Both experiments had a factorial design and four replicates with four plants per experimental unit. Data were tested by analysis of variance. During Expts. 1 and 2,16 control plants were grown under natural greenhouse conditions throughout the whole experimental period.

Almost $95 \%$ of the plants flowered after a SDT in the MGR (Tables 1 and 2), notwithstanding the low light intensities in the cells.

Table 3. Effects of $\mathrm{CO}_{2}$ concentration during culture [starting 1 month before short-day treatment (SDT)] and additional light after SDT on growth of Calathea crocata clone S (Expt. 2).

\begin{tabular}{|c|c|c|c|c|}
\hline $\begin{array}{l}\mathrm{CO}_{2} \text { level } \\
\text { (ppm) }\end{array}$ & $\begin{array}{c}\text { Additional } \\
\text { light }^{y}\end{array}$ & $\begin{array}{c}\text { Shoots } \\
\text { (no.) }\end{array}$ & $\begin{array}{c}\text { Increase } \\
\text { in leaf area } \\
\left(\mathrm{cm}^{2}\right)\end{array}$ & $\begin{array}{c}\text { Increase } \\
\text { in dry } \mathrm{wt}^{\mathrm{z}} \\
(\mathrm{g})\end{array}$ \\
\hline \multirow[t]{2}{*}{400} & None & $5.1 \pm 0.3^{x}$ & $765 \pm 178$ & $6.3 \pm 1.5$ \\
\hline & Yes & $5.6 \pm 0.4$ & $1101 \pm 205$ & $8.9 \pm 1.7$ \\
\hline \multirow[t]{2}{*}{900} & None & $5.0 \pm 0.4$ & $1188 \pm 98$ & $9.7 \pm 0.8$ \\
\hline & Yes & $5.3 \pm 0.6$ & $1462 \pm 204$ & $11.9 \pm 1.7$ \\
\hline \multicolumn{5}{|l|}{ Significance } \\
\hline $\mathrm{CO}_{2}$ & & NS & * & * \\
\hline Light & & NS & NS & NS \\
\hline $\mathrm{CO}_{2} \times$ light & & NS & NS & NS \\
\hline
\end{tabular}

${ }^{{ }^{7}}$ Measurements at the beginning (10 June 1990) and at the end (15 Nov. 1990) of the experiment.

${ }^{y}$ Additional light from high-pressure mercury-iodide lamps (photosynthetic photon flux density $=50$ $\mu \mathrm{mol} \cdot \mathrm{s}^{-1} \cdot \mathrm{m}^{-2}$ at plant level) from 0300 to $0900 \mathrm{HR}$ and from 1700 to $2130 \mathrm{HR}$.

${ }^{x}$ Indicates SE.

${ }_{N s .}^{*}$ Nonsignificant or significant at $P=0.05$, respectively, using analysis of variance. darker green leaves, and better plant quality. Van Dyk and Seydel (1985) mentioned similar positive effects. For clone $\mathrm{S}, \mathrm{CO}_{2}$ resulted in significantly more inflorescences per plant and increased the percentage of flowering plants and shoots (Table 2). For clone G, supplementary lighting after flower induction hastened flower development at natural $\mathrm{CO}_{2}$ levels. The positive effect of supplementary lighting may be even more pronounced during winter.

Depending on the start of the induction period in the MGR, flowering started in October or December. During other experiments, nearly all plants had flowers in August and September (data not shown). During these periods, the supply of flowering $C$. crocata on the European market is very limited, because natural conditions are unfavorable for flower induction. From these results and others by Pieters et al. (1989), we conclude that year-round flower induction is possible. In combination with a year-round supply of new in vitro plants, a scheduled production system is possible as follows: 1) acclimated, in vitro plants are cultivated in a greenhouse; 2) 4 months before scheduled flowering, mature plants (at least 8 to 9 months old) are transferred to an MGR for 9 weeks at $\approx 18 \mathrm{C}$ and a 10 $h$ photoperiod.

Temperature and daylength after induction are less important, and plants can be grown in a standard greenhouse. Carbon dioxide enrichment during the whole production schedule will accelerate vegetative development with positive effects on early flowering. By using an MGR for flower induction, optimal environmental control is combined with optimal use of space, thus reducing costs. In the commercial production of mushrooms [Agaricus bisporus (Lang) Sing.] and Belgian endive (Cichorium intybus L.), the use of such multilayer cells is common. Little is known, however, about the costs for using multilayer cells in commercial ornamental crop production.

\section{Literature Cited}

Bailey, L.H. 1950. The standard cyclopedia of horticulture. vol. 1. Macmillan, New York.

Kennedy, H. 1977. Systematics and pollination of the "closed-flowered" species of Calathea (Marantaceae). Univ. of California Publ. Bot. 71:1-90.

Pieters, B.,G. Boesman,P. Dehergh, and R. Lemeur. 1989. Control of flowering in Calathea crocate in multi-layer cells. Acta Hort. 246:113-120.

Schumann, K. 1902. Marantaceae. In: A. Engler (ed.). Das Pflanzenreich IV 48:1-176.

Van Dyk, P. and S. Seydel. 1985. Pflanzen wecken mit $\mathrm{CO}_{2}$ als "Lichtersatz". Zierpflanzenbau 25(7):316-319.

Vonk-Noordegraaf, C. 1980. Invloed van daglengte en temperatuur op bloei Calathea crocata. Vakblad bloemisterij 35(26):45.

Zimmer, K. 1976. Calathea crocata nach 100 Jahren aus dem DornrojschenschIafenwacht?Gartenwelt 76(10):199-201. 